Yüzüncü Yil Üniversitesi
Tarim Bilimleri Dergisi

Araştırma Makalesi (Research Article)

Investigation of Change of Yield and Yield Components in Sesame (Sesamum indicum L.) According to Years and Locations**

\author{
Mustafa YAŞAR ${ }^{* 1}$, Remzi EKINCI $^{2}$, Mehmet SEZGIN ${ }^{3}$ \\ ${ }^{1}$ Plant Production and Technologies Department, Faculty of Applied Sciences, Muş Alparslan University, 49250, \\ Muş, Turkey \\ ${ }^{2}$ Field Crops Department, Faculty of Agriculture, Dicle University, 21110, Diyarbakır, Turkey \\ ${ }^{3}$ Variety Registration and Seed Certification Center, 06170, Ankara, Turkey \\ ${ }^{1}$ https://orcid.org/0000-0001-9348-7978 ${ }^{2}$ https://orcid.org/0000-0003-4165-6631 ${ }^{3}$ https://orcid.org/0000-0002-1726-5641 \\ *Corresponding author e-mail: mustafa.yasar@alparslan.edu.tr
}

\section{Article Info}

Received: 08.11.2019

Accepted: 09.11.2020

Online Published 31.12.2020

DOI: 10.29133 /yyutbd.644514

Keywords

Location,

Sesame,

Seed yield.

\begin{abstract}
This study was carried out to investigate the characteristics of second crop sesame growing in Manisa, Antalya, İzmir, and Şanlıurfa ecological conditions between 2008 and 2012, and to shed light on future studies. Baydar2001, Muganli-57, Arslanbey, Ozberk-82, Birkan, Orhangazi-99, Hatipoglu, Boydak and BATEM-Uzun varieties were used as plant material. It seems that the change of ecological environmental conditions has very importance in the second crop sesame cultivation. In this study, while the highest seed yield was obtained from İzmir location, the lowest seed yield was obtained from Şanlıurfa location. It is concluded that Arslanbey and Hatipoglu varieties will be recommended in Sanliurfa location and BATEM-Uzun variety in Aegean and Mediterranean locations.
\end{abstract}

\title{
Susamda Lokasyon ve Yıllara Göre Verim ve Verim Unsurlarının Değişiminin Araştırılması
}

\section{Makale Bilgileri}

Geliş: 08.11.2019

Kabul: 09.11.2020

Online Yayınlanma 31.12.2020

DOI: 10.29133/yyutbd.644514

\section{Anahtar kelimeler}

Lokasyon,

Susam,

Tohum verimi.
Öz: Bu çalışma 2008-2012 yılları arasında Manisa, Antalya, İzmir ve Şanlıurfa ekolojik koşullarında yetiştirilen ikinci ürün susam bitkisinin özelliklerini incelemek ve gelecekteki çalışmalara 1şık tutmak amacıyla yapılmıştır. Bitki materyali olarak Baydar-2001, Muganl1-57, Arslanbey, Özberk-82, Birkan, Orhangazi-99, Hatipoğlu, Boydak ve BATEM-Uzun çeşitleri kullanılmıştır. Ekolojik çevresel koşullardaki değişimin, ikinci ürün susam yetiştiriciliğinde çok önemli olduğu görülmektedir. Bu çalışmada, en yüksek tohum verimi İzmir lokasyonundan elde edilirken, en düşük tohum verimi Şanlıurfa lokasyonundan elde edilmiştir. Arslanbey ve Hatipoğlu çeşitlerinin Şanlıurfa lokasyonunda ve BATEM-Uzun çeşidinin ise Ege ve Akdeniz bölgelerinde tavsiye edileceği sonucuna varılmıştır.

** This study was published as an abstract at the International Agricultural Congress of Muş Plain.

\section{Introduction}

The use of sesame seeds dates back to 3000 BC. Archaeological evidence suggests that the sesame plant was the first oil plant to be cultivated. Sesame, which has an important place in the production of vegetable oil in the world, is one of the oil plants having high percentage of oil (50- 
$60 \%$ ) and rich protein (20-25\%) (Tan, 2011). Although sesame contains 35-45\% oleic and linoleic fatty acids which are important for human nutrition, it is used as seed rather than oil industry due to difficulties in harvesting and obtaining seeds and high cost (Arslan et al., 2007; Şahin, 2014). Sesame is also resistant to oxidation compared to other vegetable oils. This feature is reported to be caused by secondary substances such as sesamine (0.5-1.5\%) and sesamoline (0.3-0.5\%). It is known that it is good for many diseases such as diabetes and anaemia due to its rich content of vitamins and minerals. It is also known to be especially effective in lowering blood cholesterol levels. (Salunkhe et al., 1991).

Sesame is a one-year bush forming plant with a short development period (90-120 days). Water, nutrient demand and soil selectivity is less, hot and drought tolerant. It is also a good crop rotation thanks to the dense fibrous root system. Usually no marketing problem is available in oil crop plant that is grown as main and secondary products in Turkey. The reasons why sesame cultivation is not developed sufficiently; inadequate cultivation techniques (16.89\%), inadequate application of fertilization (10.53\%), weed problem stemming from especially broadcast sowing (8.99\%), marketing (7.89\%), pests (3.07\%), soil preparation (2.41\%), and irrigation (2.19\%) (Dizdaroğlu and Tan, 1995; Bakal and Arıoğlu, 2020).

Sesame, which is mostly grown as second crop in the southern and south-eastern regions of Turkey, makes significant contributions to the national economy thanks to optimum land use. Harvest is done by hand due to the loss of productivity caused by machine harvesting. This creates temporary employment area in the harvest period.

According to the data of 2019; in the world, sesame cultivation area is 9.9 million ha, production is 5.5 million tons and yield is $554 \mathrm{~kg} \mathrm{ha}^{-1}$ (FAOSTAT, 2019). In Turkey, sesame cultivation area of 25985 ha, is given as 17437 tons of production and yield $670 \mathrm{kgha}^{-1}$ (TURKSTAT, 2019). Sesame cultivation in Turkey respectively; Manisa, Antalya, Uşak, Muğla, and Adana provinces are made intensively. The cultivation areas of these provinces constitute approximately $77 \%$ of the total cultivation areas. When examined in terms of yield, it is seen that the average of the provinces which are cultivated intensively is $780 \mathrm{kgha}^{-1}$ and above the world average.

In sesame seed, Turkey is an importer. Sesame seeds worthy of approximately 156 million dollars are imported. 85\% of our total sesame imports are from Nigeria, Sudan, Chad, and Ethiopia. Almost 50\% of Turkey's imports are made from Nigeria with the amount of 46 thousand tons (TURKSTAT, 2019).

This study was carried out in order to investigate some of the important features of second crop sesame production in Manisa, Antalya, İzmir, and Şanlıurfa between 2008 and 2012, and to shed light on future studies.

\section{Materials and Methods}

In this study, the data published by Ankara Seed Registration and Certification Centre Directorate were used. Experiments were established in Manisa, Antalya, İzmir and Şanlıurfa provinces where the cultivated areas are dense, and seed yield $\left(\mathrm{kg} \mathrm{da}^{-1}\right)$, plant height $(\mathrm{cm})$, days to physiological maturity (days), 50\% flowering days (days), capsule number (per plant) and branch number (per plant) properties were examined between 2008-2012. As plant material, Baydar-2001, Muganl1-57, Arslanbey, Özberk-82, Birkan, Orhangazi-99, Hatipoglu, Boydak and BATEM-Uzun varieties were used (Table 1). Information about the varieties is given in Table-1.The adjusted data were obtained from the raw data by taking the year*location as a block according to the Augmented Designs with the help of the equation given below (Peterson, 1985).

$$
\text { Adjusted Data }=\text { Raw Data }+\frac{(\text { Sum Block }- \text { Sum Means St Varieties })}{(\text { St Variesties Numbers })}
$$

The maximum temperature changes of the locations are given in Fig. 1 and humidity changes are given in Fig.2. 
Table 1. Information on varieties of sesame (Sesamum indicum L.) used as material.

\begin{tabular}{llll}
\hline Varieties & Companv/Institute & Origin & Reg. Date \\
\hline Arslanbey & GAP Agricultural Research Institute & Turkey & 15.04 .2010 \\
BATEM-Uzun & Western Mediterranean Agricultural Research Institute & Turkey & 10.04 .2013 \\
Boydak & GAP Agricultural Research Institute & Turkey & 11.04 .2012 \\
Birkan & Akdeniz University Faculty of Agriculture & Turkey & 06.04 .2011 \\
Baydar-2001 & Western Mediterranean Agricultural Research Institute & Turkey & 25.04 .2001 \\
Hatipoğlu & GAP Agricultural Research Institute & Turkey & 11.04 .2012 \\
Muganl1-57 & Western Mediterranean Agricultural Research Institute & Turkey & 28.04 .1986 \\
Orhangazi-99 & Aegean Agricultural Research Institute & Turkey & 28.04 .1999 \\
Özberk-82 & Western Mediterranean Agricultural Research Institute & Turkey & 28.04 .1986 \\
\hline
\end{tabular}

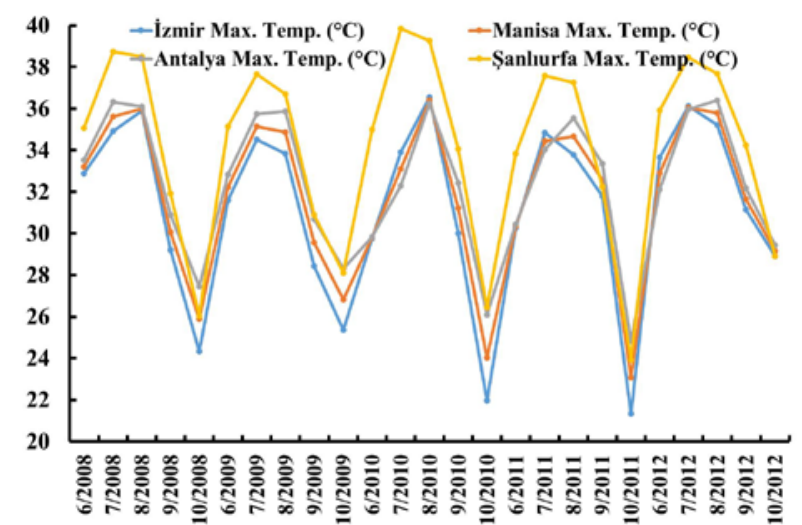

Figure. 1. Maximum temperature changes of locations (data of General Directorate of Meteorology).

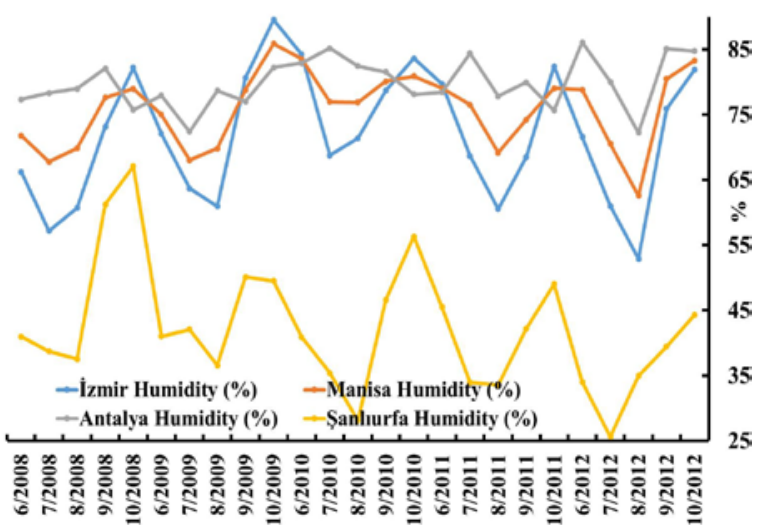

Figure. 2. Maximum humidity changes of locations (data of General Directorate of Meteorology).

\section{Results}

When seed-yield characteristic is examined in terms of years-locations 44.58-197.38 $\mathrm{kgda}^{-1}$ changes, the average is $86.45 \mathrm{kgda}^{-1}$; between locations $70.71-123.91 \mathrm{~kg} \mathrm{da}^{-1}$; and the years 49.96$108.27 \mathrm{~kg} \mathrm{da}^{-1}$ is seen to change. The highest seed-yield was obtained from İmir location and the lowest seed-yield was obtained from Şanlıurfa location. The highest seed-yield was obtained in 2012 and the lowest in 2009 (Table 3). The climate values of 2009 are quite negative in terms of sesame production. When the seed yields of the location averages of the varieties were examined; Arslanbey (109.25 $\left.\mathrm{kg} \mathrm{da}^{-1}\right)$ was obtained the highest seed-yield, while Orhangazi-99 (68.18 kgda $\left.{ }^{-1}\right)$ variety had the lowest seed-yield (Table 2). High seed-yield values in İzmir, Manisa, and Antalya locations, where Aegean and Mediterranean climates prevail, indicate that high temperature may have adversely affected the seed-yield of sesame.

When the years-locations examined in terms of plant height feature; $96.42-178.23 \mathrm{~cm}$ varies, the average is $129.38 \mathrm{~cm}$; between locations $116.82-143.10 \mathrm{~cm}$ and years $108.56-147.56 \mathrm{~cm}$ is seen that changes. The highest plant height value was obtained from Manisa location and the lowest plant height was obtained from Antalya location. The highest plant height was obtained from 2010, while the lowest plant height was obtained from 2009 (Table 3).

When the years-locations were examined in terms of days to $50 \%$ flowering days (day); 28.6775.60 days, average 38.79 days; between locations 31.14-45.97 days; the years 35.33-44.80 days, the same change is clear. The highest days to $50 \%$ flowering days (day) were obtained from the Antalya location and the lowest days to 50\% flowering days (day) were obtained from the Manisa location. The highest days to 50\% flowering days (day) was obtained in 2012, while the lowest number was obtained in 2009 (Table 3). 
Table 2. Average seed yield values of varieties by Location $\left(\mathrm{kg} \mathrm{da}^{-1}\right)$

\begin{tabular}{|c|c|c|c|c|c|c|c|}
\hline Varieties & & Antalya & Manisa & İzmir & $\begin{array}{l}\text { Şanliurfa } \\
\text { (Koruklu) }\end{array}$ & $\begin{array}{l}\text { Şanliurfa } \\
\text { (Tektek) }\end{array}$ & Means \\
\hline \multirow{10}{*}{$\begin{array}{l}\text { Seed } \\
\text { yield } \\
\left(\mathrm{kg} \mathrm{da}^{-1}\right)\end{array}$} & BATEM-Uzun & 117.13 & 120.41 & 176.98 & 38.59 & 15.59 & $93.74 \mathrm{~b}$ \\
\hline & Boydak & 67.10 & 108.95 & 137.17 & 100.50 & 116.05 & 105.95 a \\
\hline & Birkan & 71.29 & 79.40 & 85.04 & 60.22 & 45.08 & $68.21 \mathrm{~d}$ \\
\hline & Baydar-2001 & 80.43 & 85.36 & 136.68 & 62.06 & 54.89 & $83.88 \mathrm{c}$ \\
\hline & Hatipoğlu & 62.15 & 64.00 & 130.14 & 104.81 & 117.59 & $95.74 \mathrm{~b}$ \\
\hline & Arslanbey & 69.06 & 91.79 & 123.31 & 133.69 & 128.38 & $109.25 \mathrm{a}$ \\
\hline & Muganl1-57 & 64.02 & 82.56 & 80.03 & 68.27 & 60.81 & $71.14 \mathrm{~d}$ \\
\hline & Orhangazi-99 & 69.18 & 69.38 & 129.12 & 38.17 & 34.90 & $68.15 \mathrm{~d}$ \\
\hline & Özberk-82 & 76.04 & 89.41 & 116.76 & 64.43 & 63.11 & 81.95 c \\
\hline & Means & 75.16 c & $87.92 \mathrm{~b}$ & $123.91 \mathrm{a}$ & $74.53 \mathrm{c}$ & $70.71 \mathrm{c}$ & \\
\hline
\end{tabular}

When the years-locations were examined in terms of the days to physiological maturity (days), 90.00-121.88 days showed a change, while the average was 101.71 days; i.e. a change between locations 97.22-100.94 days and between the years 99.50-105.93 days are observed. The highest days to physiological maturity (days) was obtained from Manisa location and the lowest day to physiological maturity (days) was obtained from İzmir location. The highest day to physiological maturity (days) was obtained in 2008 and the lowest in 2010 (Table 3).

When the years-locations were examined in terms of the capsule number (per plant), it was found that 55.00-337.86 (per plant) changes and average 142.84 (per plant), between locations 88.63236.34 (per plant) and the years 95.67-159.80 (per plant) is seen to change. The highest capsule number (per plant) was obtained from Manisa location and the lowest one was obtained from Antalya location. The highest capsule number (per plant) was obtained from 2012, while the lowest one was obtained from 2010 (Table 3).

When the years-locations were examined in terms of the capsule number (per plant), it was found that 55.00-337.86 (per plant) changes and average 142.84 (per plant), between locations 88.63236.34 (per plant) and the years 95.67-159.80 (per plant) is seen to change. The highest capsule number (per plant) was obtained from Manisa location and the lowest one was obtained from Antalya location. The highest capsule number (per plant) was obtained from 2012, while the lowest one was obtained from 2009 (Table 3).

When the yields of all varieties are evaluated on the basis of locations; the highest seed-yield was obtained from İzmir location with $176.98 \mathrm{kgda}^{-1}$, and the lowest seed-yield was obtained from BATEM-Uzun variety with Şanlıurfa (Tektek) location with $15.59 \mathrm{kgda}^{-1}$. Antalya location, the highest seed-yield $117.13 \mathrm{kgda}^{-1}$ with the BATEM-Uzun variety, the lowest seed-yield $62.15 \mathrm{~kg} \mathrm{da}^{-1}$ with the Hatipoglu variety was obtained. Manisa (Beydere) location, the highest seed-yield $120.41 \mathrm{~kg}$ $\mathrm{da}^{-1}$ BATEM-Uzun variety, the lowest seed-yield $64.00 \mathrm{~kg} \mathrm{da}^{-1}$ with Hatipoglu variety, was obtained. The lowest seed-yield was obtained from Muganl1-57 variety with $80.03 \mathrm{~kg} \mathrm{da}^{-1}$ and the highest yield from BATEM-Uzun variety with $176.98 \mathrm{~kg} \mathrm{da}^{-1}$. Şanlıurfa (Koruklu) location, the lowest seed-yield $38.17 \mathrm{~kg} \mathrm{da}^{-1}$ with the Orhangazi-99 variety, the highest seed-yield $133.69 \mathrm{~kg} \mathrm{da}^{-1}$ was obtained from the Arslanbey variety. Şanliurfa (Tektek) location, the lowest seed-yield $15.59 \mathrm{~kg} \mathrm{da}^{-1}$ with the BATEM-Uzun variety, the highest seed-yield $128.38 \mathrm{~kg} \mathrm{da}^{-1}$ with the Arslanbey variety was obtained (Table 3). 
Table 3. Location and years values of the traits examined

\begin{tabular}{|c|c|c|c|c|c|c|c|}
\hline & Locatio & & & & & & \\
\hline Traits & Years & Antalya & Manisa & İzmir & Șanlıurfa (Koruklu) & Şanlıurfa (Tektek) & Means \\
\hline \multirow{6}{*}{$\begin{array}{l}\text { Seed yield } \\
\left(\mathrm{kg} \mathrm{da}^{-1}\right)\end{array}$} & 2008 & 75.33 & 81.18 & 90.00 & 108.79 & 99.29 & 90.92 \\
\hline & 2009 & 44.58 & 54.92 & 44.28 & 59.58 & 46.42 & 49.96 \\
\hline & 2010 & 65.21 & 109.98 & 127.88 & 86.38 & 71.91 & 92.27 \\
\hline & 2011 & 84.00 & 90.62 & 160.01 & 53.51 & 65.94 & 90.81 \\
\hline & 2012 & 106.71 & 102.90 & 197.38 & 64.37 & 70.00 & 108.27 \\
\hline & Means & 75.16 & 87.92 & 123.91 & 74.53 & 70.71 & 86.45 \\
\hline \multirow{6}{*}{$\begin{array}{l}\text { Plant height } \\
(\mathrm{cm})\end{array}$} & 2008 & 123.50 & 130.75 & 125.00 & 134.25 & 118.75 & 126.45 \\
\hline & 2009 & 110.00 & 113.02 & 98.48 & 124.87 & 96.42 & 108.56 \\
\hline & 2010 & 121.79 & 153.76 & 146.01 & 178.23 & 138.01 & 147.56 \\
\hline & 2011 & 114.00 & 158.16 & 133.76 & 104.07 & 123.87 & 126.77 \\
\hline & 2012 & 114.80 & 159.80 & 160.50 & 125.72 & 127.00 & 137.56 \\
\hline & Means & 116.82 & 143.10 & 132.75 & 133.43 & 120.81 & 129.38 \\
\hline \multirow{6}{*}{$\begin{array}{l}\text { Days to } 50 \% \\
\text { flowering days } \\
\text { (day) }\end{array}$} & 2008 & 47.25 & 32.75 & 40.40 & 40.25 & 40.50 & 40.23 \\
\hline & 2009 & 35.00 & 28.67 & 33.17 & 40.00 & 39.83 & 35.33 \\
\hline & 2010 & 38.00 & 29.50 & 37.13 & 41.25 & 39.25 & 37.03 \\
\hline & 2011 & 34.00 & 32.57 & 33.00 & 41.57 & 41.57 & 36.54 \\
\hline & 2012 & 75.60 & 32.20 & 33.60 & 41.60 & 41.00 & 44.80 \\
\hline & Means & 45.97 & 31.14 & 35.46 & 40.93 & 40.43 & 38.79 \\
\hline \multirow{6}{*}{$\begin{array}{l}\text { Days to } \\
\text { physiological } \\
\text { maturity } \\
\text { (days) }\end{array}$} & 2008 & 102.50 & 121.25 & 92.00 & 90.00 & 91.75 & 99.50 \\
\hline & 2009 & 101.00 & 119.33 & 97.00 & 97.67 & 97.33 & 102.47 \\
\hline & 2010 & 105.00 & 121.88 & 102.88 & 101.25 & 98.63 & 105.93 \\
\hline & 2011 & 101.00 & 108.00 & 92.43 & 101.57 & 102.43 & 101.09 \\
\hline & 2012 & 95.20 & 99.20 & 101.80 & 101.60 & 100.00 & 99.56 \\
\hline & Means & 100.94 & 113.93 & 97.22 & 98.42 & 98.03 & 101.71 \\
\hline \multirow{6}{*}{$\begin{array}{l}\text { Capsule } \\
\text { number } \\
\text { (per plant) }\end{array}$} & 2008 & 73.75 & 225.50 & 155.00 & 174.75 & 146.00 & 155.00 \\
\hline & 2009 & 98.00 & 147.50 & 87.17 & 90.67 & 55.00 & 95.67 \\
\hline & 2010 & 94.00 & 183.63 & 197.13 & 97.00 & 197.13 & 153.78 \\
\hline & 2011 & 95.00 & 337.86 & 166.86 & 64.57 & 85.43 & 149.94 \\
\hline & 2012 & 82.40 & 287.20 & 227.00 & 92.40 & 110.00 & 159.80 \\
\hline & Means & 88.63 & 236.34 & 166.63 & 103.88 & 118.71 & 142.84 \\
\hline \multirow{6}{*}{$\begin{array}{l}\text { Branch } \\
\text { Number } \\
\text { (per plant) }\end{array}$} & 2008 & 2.50 & 6.00 & 4.60 & 4.00 & 3.75 & 4.17 \\
\hline & 2009 & 4.50 & 6.00 & 4.83 & 3.50 & 3.33 & 4.43 \\
\hline & 2010 & 3.88 & 5.00 & 5.63 & 3.38 & 3.88 & 4.35 \\
\hline & 2011 & 4.35 & 5.86 & 6.29 & 2.70 & 2.53 & 4.34 \\
\hline & 2012 & 3.20 & 5.80 & 5.40 & 2.80 & 4.30 & 4.30 \\
\hline & Means & 3.69 & 5.73 & 5.35 & 3.28 & 3.56 & 4.32 \\
\hline
\end{tabular}

\section{Discussion and Conclusion}

It is thought that sesame genotypes show different responses in different environmental conditions and show ecological performance due to the genetic structure of the genotypes. This situation reveals the necessity of determining the performances of lines/varieties according to environmental conditions and suggesting different genotypes to different environments. Thus, the best result can be obtained from the genotype showing good performance according to ecological environmental conditions. As in many field crops, studies to determine the environmental performance of new lines in sesame plants are of great importance in terms of production and efficiency. It has been determined that environmental conditions, which have changed over the years, greatly affect sesame performance. It has been revealed that the ecological conditions of Izmir differ greatly from the other ecological conditions studied. Our findings in terms of seed yield characteristics are similar to the findings of Cürat (2010), Ulukütük (2011), Dossa et al. (2019), and Bakal and Arığlu (2020).

High seed-yield values of BATEM-Uzun variety were obtained especially in Aegean and Mediterranean regions, but low seed-yield values were obtained in Şanlıurfa location. Arslanbey and Hatipoglu varieties were obtained in Şanlıurfa locations with high seed-yield values. In this case, 
Arslanbey and Hatipoglu varieties in Şanliurfa location and BATEM-Uzun variety in Aegean and Mediterranean locations are recommended.

The second crop is in sesame cultivation, change of ecological environmental conditions is quite important; the highest seed-yield was obtained from İzmir location, and the lowest seed-yield was obtained from Şanlıurfa location. It is concluded that Arslanbey and Hatipoglu varieties will be recommended in Şanliurfa location, and BATEM-Uzun variety in Aegean and Mediterranean locations.

\section{References}

Arığlu, H. (2007). Breeding and Cultivation of Oil Crops. Cukurova University Faculty of Agriculture Publishing, No:220 s 142 Adana.

Arslan, Ç., Uzun, B., Ülger, S., \& Çağırgan, M. (2007). Determination of oil content and fatty acid composition of sesame mutants suited for intensive management conditions. Journal of American Oil Chemists' Society, 84, 917-920.

Bakal, H., \& Arığlu, H. (2020). Determination of Some Important Agronomic and Quality Characteristics of Registered Sesame (Sesamum indicum L.) Varieties Grown as a Main Crop in Mediterranean Region (Turkey). Journal of the Faculty of Agriculture, Turkey 13. National, First International Crop Science Congress Special Issue: 218-225, 2020, ISSN 1304-9984.

Cürat, D. (2010). Determination of biological and chemical properties of local sesame (Sesamum indicum L.) populations grown in kilis and its region. Master Thesis, Kilis 7 Aralık University, Institute of Science.

Dizdaroğlu, T. \& A.Ş. Tan. (1995). The second crop sesame production and problems in Aegean Region. Anadolu J. of ARRI5 (1), 48-73. Menemen. İzmir.

Dossa, K., Li, D., Zhou, R., Yu, J., Wang, L., Zhang, Y., You, J., Liu, A., Mmadi, M.A., Fonceka, D., Diouf, D., Cissé, N., Wei, X. \& Zhang, X. (2019). The genetic basis of drought tolerance in the high oil crop Sesamum indicum. Plant Biotechnol J, 17, 1788-1803.

FAOSTAT. (2019). (http://www.fao.org/faostat/en/\#home) Date access: 20.08.2019.

Peterson, R.G. (1985). Augmented Designs for preliminary yield tirals (Revised). Rachis Vol. 4, No:1 p: 27-32; Jan, 1985.

Salunkhe, D. K., Chavan, J. K., Adsule, R. N. \& Kadam, S. S. (1991). Sesame in world oilseeds: Chemistry, technology and utilization. Van Nostrand and Reinhold, New York. Şahin, G., 2014 Sesame (Sesamum indicum L.) As An Important Oil Plant With Decreasing Production, Journal of the Human and Social Science Researches,3 (2).

Tan, Ş. (2011). Yield Potential of some Sesame Cultivars in Menemen Conditions. Anadolu, J. of AARI 21 (2), 11 - 28.

TURKSTAT. (2019). http://tuik.gov.tr/Start.do Date access: 20.08.2019.

Ulukütük, E. (2011). Comparison of yield and quality parameters of local sesame (Sesamum indicum L.) populations collected from Kilis region. Master Thesis, Kilis 7 Aralık University, Institute of Science. 